\title{
Bankruptcy Prediction Models in Galician companies. Application of Parametric Methodologies and Artificial Intelligence*
}

\author{
Pablo de Llano Monelos ${ }^{1}$, Manuel Rodríguez López ${ }^{2}$, Carlos Piñeiro \\ Sánchez $^{3}$
}

\begin{abstract}
:
This paper provides empirical evidence on the prediction of non-financial companies' failure. We develop several models to evaluate failure risk in companies from Galicia. We check the predictive ability of parametric models (multivariate discriminant, logit) compared with auditor's report. Models are based on relevant financial variables and ratios, in financial logic and $a$ in financial distress situations. We examine a random sample of companies in cross-sectional perspective, checking the predictive capacity at any given time, also verifying is models give reliable signals to anticipate future events of financial distress. Findings suggest that our models are extremely effective when applied in medium and long term, and that they offer higher predictive capabilities than external audit.
\end{abstract}

\section{Key Words:}

Business Failure, Financial Distress, Prediction of Insolvency, Audit Reports

JEL Classification: G33, C45, C59

\footnotetext{
* Acknowledgement: A previous, limited version of this paper was discussed in ASEPUC Conference 2010.

${ }^{1}$ Universidade da Coruña Finance and Management Information Systems Research Group (FYSIG), e-mail:pdellano@udc.es

${ }^{2}$ Universidade da Coruña Finance and Management Information Systems Research Group (FYSIG), e-mail:marod@udc.es

${ }^{3}$ Universidade da Coruña Finance and Management Information Systems Research Group (FYSIG), e-mail: carpi@udc.es
} 
International Journal of Economics \& Business Administration, I (1), 2013

118 Pablo de Llano Monelos - Manuel Rodríguez López- Carlos Piñeiro Sánchez

\section{Introduction}

Business failure has been, and will undoubtedly be in the future, a topic of special interest for a wide range of operators. Company extinction usually has severe consequences for a broad set of agents: owners, creditors, employees, administration and other members of value system and the society. It is difficult to anticipate these situations in an efficient and effective way, hence the description of the failure process and the development of predictive modelling are major issues for academics and practitioners.

External audit should provide reliable evidences to predict business failure. In fact, auditors are engaged to audit financial statements assuming that the company will continue as a going concern, therefore they are expected to issue a going-concern opinion prior to the bankruptcy filing.

Some authors have reported that companies with qualified opinion experience more, and more intense, episodes of financial distress (Wilkins, 1997). But also, an abnormally high number of failed companies received qualified opinions, and even clean reports (Venuti, 2004; Arnedo et al., 2008). Qualifications can also be very different in nature - minor uncertainties, difficulties to gather some documents or information and severe events that can threaten company's survival -, and this degrades auditor's reporting quality. McKee (2003) estimates the auditor signalling rate for bankrupt companies in 50\%.

These anomalies may reflect distortions in the independence (Simunic, 1984; Carcello and Palmrose, 1994; Schwartz and Soo, 1995; Ruiz and Gomez, 2001; Lam and Mensah, 2006; Robinson, 2008; Thalassinos, Liapis and Thalassinos, 2013) or biases in evidence evaluation - it has been suggested that auditors might have an unconscious bias towards business continuity (O'Clock and Devine, 1995). Auditors are reluctant to include going concern disclosures because such a new can cause financial distress by itself - this is the self-fulfilling prophesy hypothesis.

Based on seminal evidence provided by Beaver (1966) and Altman (1968), research has focused on the analysis of the external profile of financial failure: temporary insolvency, delays, bankruptcy. The goal is to itemize the main financial processes involved in financial distress, to build a predictive model. Several techniques have been applied: multiple discriminant analysis (Altman, 1968; Altman, Haldeman and Narayanan, 1977), conditional probability and probit - logit (Martin 1977; Ohlson, 1980; Zmijewski, 1984), recursive partitioning (Frydman, Altman and Kao, 1985) and artificial intelligence applications, both expert systems and artificial neural networks (Messier and Hansen, 1988; Bell, Ribar and Verchio, 1990; Hansen and Messier, 1991; Serrano and Martin del Brio, 1993; Koh and Tan, 1999; Brockett et al., 2006). Some models are built upon fuzzy set theory and fuzzy logic (Dubois and Prade, 1992; Slowinski and Zopounidis, 1995; McKee and Lensberg, 2002) more 
recently, heuristic techniques have been applied to build multicriteria analysis models combining group decision support systems (GDSS) applications and recognized qualitative methods, such as the Analytic Hierarchy Process (AHP) (Sun and Li, 2009).

A recurrent obstacle is the identification of a reduced set of variables that can reliably describe and predict financial distress. There seems to be consensus on the relevance of financial information, including financial ratios; but it is also evident that more, and more diverse, information is needed. Some experiments have tested the use of criteria other than accrual (Elam, 1975; Norton and Smith, 1979; Platt, Platt and Pedersen, 1994) the effect of macroeconomic magnitudes (Rose, Andrews, and Giroux, 1982), and proxies intended to reveal internal events associated with failure, e.g. late submission of the Annual Accounts, qualifications in audit reports, and management skills (Peel, Peel and Pope, 1986; Keasey and Watson, 1987).

Predicting business failure has also been a growing concern in Spain in recent years. Some models have been developed for banking (Laffargue, Martin Vasquez, 1985; Pina, 1989; Rodríguez 1989; Martin del Brio and Serrano, 1993), insurance industry (Rodríguez Acebes, 1990; Lopez, Moreno and Rodriguez 1994; and Mora, 1994a), textile industry (Somoza, 2001) and also generalized models for non-financial entities and SMEs (Gabás, 1990; Garcia, Arqués y Calvo-Flores, 1995; Ramirez, 1996; Lizarraga, 1997). Some other models have been developed to meet the particularities of industries in limited geographical areas (e.g. Valencia, see Gandia, Garcia and Molina, 1995; Gallego Gómez and Yanez, 1996; Ferrando and White, 1998). This specialization, far from leading to inconsistency, is convenient because the predictive ability is conditioned by the profile of sampled companies and socioeconomic context. Therefore further implementation of the models requires a reassessment of coefficients (Moyer, 1977; Altman, 2000). We have few specific models for Galician companies; an effort to harmonize the specification and weights of factors is also needed.

Time frame is also relevant. It should be noted that, even though we can build and test models for different frames, the decision maker doesn't know whether the company is going to fail or not, neither when this event will happen. Pina (1989) and Mora (1994b) suggested the use of inter-temporal models; we intend to put them together in order to evaluate the internal coherence of predictions, and make a more informed opinion of financial failure risk.

This paper has three objectives:

1. Design models able to accurately identify businesses at risk of insolvency or failure, in the Galician socio-economic context, and contrast the stability of its predictions in the short, medium and long term.

2. Provide empirical evidence about the relevance of accounting information and financial ratios to evaluate the company's financial stability. 
3. Verify the capacity of external auditors to anticipate financial distress and provide empirical evidence to determine if changes in auditor opinion can be interpreted as signs of financial stress.

First, we offer an outline of the estimation process and a comparison of forecasting models; then, we discuss model prediction capacity. Finally, we evaluate the relative effectiveness of warning signs supplied by auditors' reports.

\section{Estimation and validation of the models}

\subsection{Sampling}

The population under study is active companies based in Galicia, identified according to data supplied by the SABI database, in financial distress situation. We excluded companies with less than four years old, in order to debug the effect of initial mortality, and also those for which there were information gaps affecting the estimation of the models, in particular all those whose reports were not available. We also excluded companies in real estate industry, whose current situation would undoubtedly induce biases in model estimation. This matching strategy is justified because failed companies usually are a small proportion of the population: therefore population proportions are much more favourable for healthy, so a conventional random sampling would provide poor information of failure events and would lead to inefficient estimators.

We use a broad interpretation of financial failure, based on the modern view that includes several financial stress situations that are not necessarily a bankruptcy. The conventional definition of failure is appealing because it provides an objective and exhaustive classification, but it does not reflect events of tension such as liquidity shortages or funding problems in the short term (Pindado, Rodrigues and Torre, 2008) that do not necessarily lead to an immediate extinction of the company. Thus, out definition of financial distressed company include all those companies in population that verify one or more of the following conditions:

- Is filing for bankruptcy;

- Is involved in claims, in large amounts;

- Has refused several trade effects and is included in public logs such as BADEXCUG and RAI.

Models have been estimated upon a sample of 120 firms, relying in financial data from 1990 to 1997. 


\subsection{Variables}

Table 1: Financial ratios

\begin{tabular}{|c|c|c|c|c|c|}
\hline \multirow{5}{*}{ 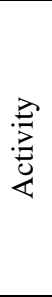 } & ACT01 & $\begin{array}{c}\text { Financial Expenses / Added } \\
\text { Value }\end{array}$ & \multirow{6}{*}{ 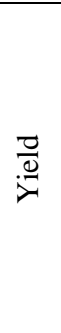 } & REN01 & EBIT / Assets \\
\hline & ACT02 & Personal Expenses / Fixed Asset & & REN02 & EBIT / Sales \\
\hline & ACT03 & $\begin{array}{c}\text { (Cost Employees + } \\
\text { Depreciation)/ Added Value }\end{array}$ & & REN03 & Net Result / Sales \\
\hline & ACT04 & $\begin{array}{l}\text { Operating Income/ Operating } \\
\text { Consumption }\end{array}$ & & REN04 & $\begin{array}{c}\text { (Net Res. - Available - } \\
\text { Stocks) / Assets) }\end{array}$ \\
\hline & ACT05 & Added Value / Sales & & REN05 & Net Result / Assets \\
\hline \multirow{4}{*}{ 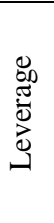 } & APL01 & P.B.I.T. / Financial Expenses & & REN06 & Net Result / Equity \\
\hline & APL02 & $\begin{array}{c}\text { Financial Expenses / Total } \\
\text { Liabilities }\end{array}$ & \multirow{8}{*}{ 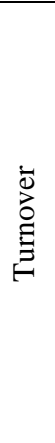 } & ROT01 & $\begin{array}{l}\text { (Current Assets - Stocks) / } \\
\text { Sales }\end{array}$ \\
\hline & APL03 & $\begin{array}{c}\text { Operating Result. / Financial } \\
\text { Expenses }\end{array}$ & & ROT02 & Stocks / Sales \\
\hline & APL04 & Period Result / Total Liabilities & & ROT03 & Sales / Realizable Assets \\
\hline \multirow{4}{*}{ 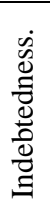 } & END01 & Total Liabilities / Equity & & ROT04 & Sales / Current Assets \\
\hline & END02 & $\begin{array}{c}\text { (Equity -Period Result) / } \\
\text { Current Liabilities }\end{array}$ & & ROT05 & Sales / Fixed Assets \\
\hline & END03 & Equity / Liabilities & & ROT06 & Sales / Assets \\
\hline & END04 & $\begin{array}{l}\text { Long-Term Liabilities And } \\
\text { Equity / Liabilities }\end{array}$ & & ROT07 & Sales / Working Capital \\
\hline \multirow{8}{*}{ 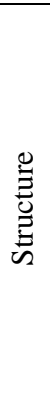 } & EST01 & Current Assets / Assets & & ROT08 & Sales / Available Assets \\
\hline & EST02 & $\begin{array}{c}\text { Equipment Depreciation / } \\
\text { Non-Current Assets }\end{array}$ & \multirow{9}{*}{$\begin{array}{l}\text { 己े } \\
\text { Ḋ } \\
\text { D } \\
\text { 心 }\end{array}$} & SOL01 & $\begin{array}{c}\text { (Current Assets - Stocks) / } \\
\text { Current Liabilities }\end{array}$ \\
\hline & EST03 & Working Capital / Assets & & SOL02 & Current Assets / Liabilities \\
\hline & EST04 & Working Capital / Liabilities & & SOL03 & $\begin{array}{c}\text { Current Assets / Curren } \\
\text { Liabilities }\end{array}$ \\
\hline & EST05 & Working Capital / Sales & & SOL04 & Fixed Assets / Equity \\
\hline & EST06 & Cash \& Equivalent / Assets & & SOL05 & Current Liabilities / Assets \\
\hline & EST07 & Net Result / Working Capital & & SOL06 & Equity / Assets \\
\hline & EST08 & $\begin{array}{c}\text { Measurement Decomposition } \\
\text { Assets }\end{array}$ & & SOL07 & Equity/ Fixed Assets \\
\hline \multirow{13}{*}{ 坣 } & LIQ01 & Operative Cash Flow / Assets & & SOL08 & Current Liabilities / Assets \\
\hline & LIQ02 & $\begin{array}{c}\text { Operative Cash Flow / } \\
\text { Liabilities }\end{array}$ & & SOL09 & $\begin{array}{c}\text { Pre-tax Profit/ Current } \\
\text { Liabilities }\end{array}$ \\
\hline & LIQ03 & $\begin{array}{l}\text { Operative Cash Flow / } \\
\text { Current Liabilities }\end{array}$ & \multirow{2}{*}{$\underset{\widetilde{n}}{\stackrel{5}{\pi}}$} & TES01 & Cash / Current Liabilities \\
\hline & LIQ04 & Operative Cash Flow / Sales & & TES02 & Cash / Sales \\
\hline & LIQ05 & Cash Flow / Assets & & & \\
\hline & LIQ06 & Cash Flow / Liabilities & & & \\
\hline & LIQ07 & Cash Flow / Current Liabilities & & & \\
\hline & LIQ08 & Resources Generated CF / Sales & & & \\
\hline & LIQ09 & Available / Current Liabilities & & & \\
\hline & LIQ10 & Stocks / Current Liabilities & & & \\
\hline & LIQ11 & $\begin{array}{c}\text { Stocks + Liquid Asset / } \\
\text { Current Liabilities }\end{array}$ & & & \\
\hline & LIQ12 & Interval Without Credit & & & \\
\hline & LIQ13 & Available / Current Liabilities & & & \\
\hline
\end{tabular}


The choice of predictor variables is problematic due to the absence of a consolidated theory about business failure, the subsequent use of multiple subsets makes experimental results are not comparable, cross or temporarily. In our case the selection was based on two principles: popular in accounting and financial literature, and the frequency and level of significance in those studies more relevant to the prediction of business failure. In all cases, the ratios were calculated from the magnitudes listed in the Annual Accounts, without adjustments previously seen in literature as the valuation at market prices or using alternative accounting methods.

\subsection{Factor analysis}

Prior to model estimation, a factor analysis was performed to reduce the initial set of variables to a small number of synthetic, uncorrelated regressors. This is an important issue given that, as Lev (1978) states, financial ratios usually move in the same direction because they are built upon common components and because financial processes are interrelated.

All models require at least four factors to count with more than $50 \%$ of variance; the first factors are related to profitability, liquidity (cash flow and generated resources), the level of debt and creditworthiness. These results confirm, once again, the relationship between profitability ratios and cash flow, as stated by Gombola and Ketzer (1983) and Pina (1992). In the first three years prior to the failure the nature and sequence of these factors is similar, but not in the fourth one.

\subsection{Multivariate Models}

The estimation was performed using parametric multivariate techniques: multiple linear regression analysis, linear discriminant analysis and logit analysis, using step selection. This selection method does not guarantee an optimal final set of regressors, given that the selection is based on conditional contrasts, but is and efficient and logical strategy to find a good combination of variables and is consistent with the philosophy of making manageable and understandable models.

This methodology has been applied to develop absorbent models for each of the four years of planning horizon - these are the "Omega Models". The following tables (Table 2 to

Table 5) summarize the composition of these models, the significance levels of variables, the estimates, and the percentages of success.

Finally, we estimate a single model comprising all the available observations for the four years (

Table 6). This model is intended to integrate the four partial models, and to give a generic, time-independent prediction; it is also intended to support a sensitivity analysis to test the significance and stability of the estimates. 
Bankruptcy Prediction Models in Galician Companies Application of Parametric Methodologies and Artificial Intelligence

Table 2: Models “Omega-1” - 1 year before the failure

\begin{tabular}{|c|c|c|c|c|c|c|c|}
\hline & \multirow[t]{2}{*}{ Variables } & \multicolumn{2}{|c|}{ MDA } & \multicolumn{2}{|c|}{ Logit } & \multicolumn{2}{|l|}{ LR } \\
\hline & & Coef.(f) & Sig. & Coef.(t) & Sig. & Coef.(wald) & Sig. \\
\hline \multirow{2}{*}{ Apl04 } & \multirow{2}{*}{ Profit / loans } & 4,284 & & $-110,66$ & & $-1,068$ & \\
\hline & & $-106,2$ & 0 & $-7,55$ & 0,01 & $(-6,89)$ & 0 \\
\hline \multirow{2}{*}{ End03 } & \multirow{2}{*}{ Equity / loans } & \multirow{2}{*}{ - } & \multirow{2}{*}{-} & 5,584 & & \multirow{2}{*}{ 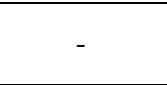 } & \multirow{2}{*}{-} \\
\hline & & & & $-2,78$ & 0,1 & & \\
\hline \multirow{2}{*}{ Rot06 } & \multirow{2}{*}{$\begin{array}{l}\text { Sales / total } \\
\text { assets }\end{array}$} & 0,201 & & $-2,603$ & & $-0,005$ & \\
\hline & & $-52,35$ & 0 & $-4,38$ & 0,04 & $(-1,98)$ & 0,05 \\
\hline \multirow{2}{*}{ Sol06 } & \multirow{2}{*}{$\begin{array}{l}\text { Equity / total } \\
\text { assets }\end{array}$} & 1,311 & & 30,815 & & $-0,327$ & \\
\hline & & $-74,69$ & 0 & $-7,21$ & 0,01 & $(-4,71)$ & 0 \\
\hline \multirow{4}{*}{ Liq12 } & \multirow{2}{*}{ No credit period } & \multirow{2}{*}{ - } & \multirow{2}{*}{-} & 2,929 & & \multirow{2}{*}{ 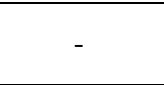 } & \multirow{2}{*}{-} \\
\hline & & & & $-4,67$ & 0,03 & & \\
\hline & \multirow{2}{*}{ Intercept } & $-0,339$ & \multirow{2}{*}{ - } & 8,444 & & 0,584 & \\
\hline & & - & & $-7,34$ & 0,01 & $-11,41$ & 0 \\
\hline & \multirow{2}{*}{ Global sig. } & 99,736 & \multirow{2}{*}{0} & 149,958 & \multirow{2}{*}{0} & 52,353 & \multirow{2}{*}{0} \\
\hline & & $(2)$ & & $(2)$ & & (f) & \\
\hline & $\begin{array}{c}\text { Hit rate, failed } \\
\text { companies }\end{array}$ & $81,70 \%$ & & $98.3 \%$ & & $81,70 \%$ & \\
\hline & $\begin{array}{c}\text { Hit rate, healthy } \\
\text { companies }\end{array}$ & $100,00 \%$ & & $96,70 \%$ & & $100,00 \%$ & \\
\hline & $\begin{array}{l}\text { Hit rate, all } \\
\text { companies }\end{array}$ & $90,80 \%$ & & $97,50 \%$ & & $90,80 \%$ & \\
\hline
\end{tabular}

Table 3: Models “Omega-2” - 2 years before the failure

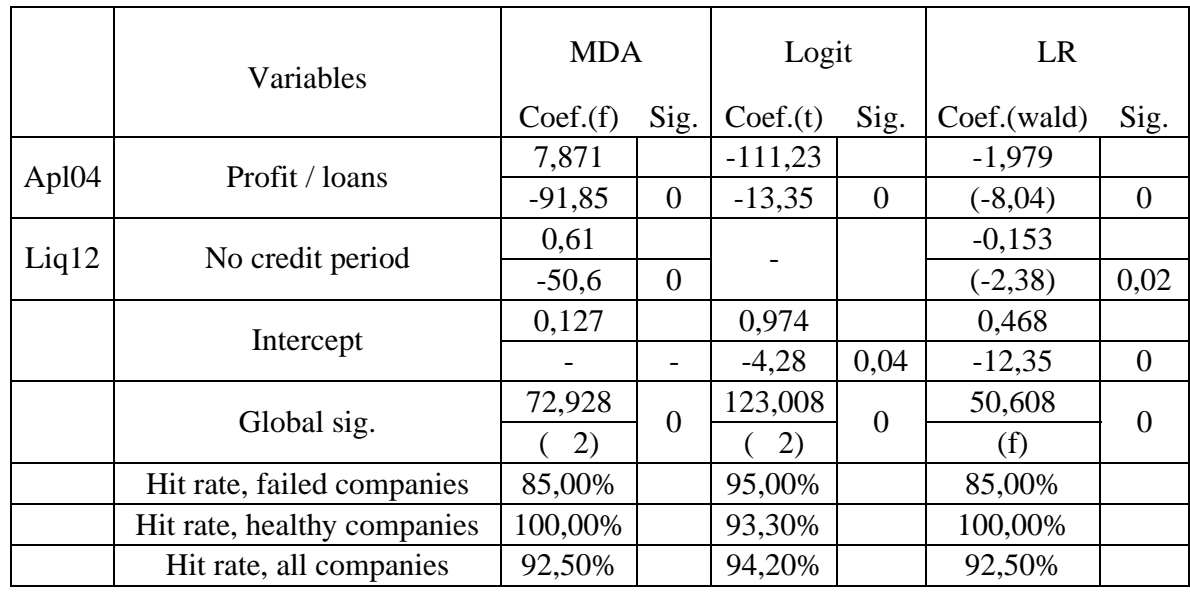

Table 4: Models "Omega-3" - 3 years before the failure

\begin{tabular}{|c|c|c|c|c|c|c|c|}
\hline & \multirow{2}{*}{ Variables } & \multicolumn{2}{|c|}{ MDA } & \multicolumn{2}{|c|}{ Logit } & \multicolumn{2}{|l|}{ LR } \\
\hline & & Coef.(f) & Sig. & Coef.(t) & Sig. & Coef.(wald) & Sig. \\
\hline \multirow{2}{*}{ Ren05 } & \multirow{2}{*}{ Profit / total as sets } & 13,706 & & $-33,765$ & & $-3,308$ & \\
\hline & & $-17,7$ & 0 & $-14,67$ & 0 & $(-4,19)$ & 0 \\
\hline
\end{tabular}


International Journal of Economics \& Business Administration, I (1), 2013

124 Pablo de Llano Monelos - Manuel Rodríguez López- Carlos Piñeiro Sánchez

\begin{tabular}{|c|c|c|c|c|c|c|c|}
\hline \multirow{2}{*}{ Sol06 } & \multirow{2}{*}{ Equity / total assets } & 2,108 & & $-6,216$ & & $-0,509$ & \\
\hline & & $-40,38$ & 0 & $-11,35$ & 0 & $(-3,46)$ & 0 \\
\hline \multirow{9}{*}{ Liq05 } & \multirow{2}{*}{$\begin{array}{l}\text { Cash flow Resources } \\
\text { Generated / total assets }\end{array}$} & $-7,734$ & & \multirow{2}{*}{ - } & \multirow{2}{*}{ - } & 1,867 & \\
\hline & & $-16,88$ & 0 & & & $-3,75$ & 0 \\
\hline & \multirow{2}{*}{ Intercept } & $-0,98$ & & 1,678 & & 0,524 & \\
\hline & & - & - & $-10,42$ & 0 & $-8,92$ & 0 \\
\hline & \multirow{2}{*}{ Global sig. } & 51,182 & \multirow{2}{*}{0} & 85,743 & \multirow{2}{*}{0} & 21,331 & \multirow{2}{*}{0} \\
\hline & & $(2)$ & & $(2)$ & & (f) & \\
\hline & Hit rate, failed companies & $73,30 \%$ & & $93,30 \%$ & & $73,30 \%$ & \\
\hline & Hit rate, healthy companies & $93,30 \%$ & & $91,70 \%$ & & $93,30 \%$ & \\
\hline & Hit rate, all companies & $83,30 \%$ & & $92,50 \%$ & & $83,30 \%$ & \\
\hline
\end{tabular}

Table 5: Models "Omega-4" - 4 years before the failure

\begin{tabular}{|c|c|c|c|c|c|c|c|}
\hline & \multirow[t]{2}{*}{ Variables } & \multicolumn{2}{|c|}{ MDA } & \multicolumn{2}{|c|}{ Logit } & \multicolumn{2}{|l|}{ LR } \\
\hline & & Coef.(f) & Sig. & Coef.(t) & Sig. & Coef.(wald) & Sig. \\
\hline \multirow{2}{*}{ Apl04 } & \multirow{2}{*}{ Profit / loans } & 6,53 & & $-49,448$ & & $-1,586$ & \\
\hline & & $-26,01$ & 0 & $-18,79$ & 0 & $(-4,73)$ & 0 \\
\hline \multirow{2}{*}{ End03 } & \multirow{2}{*}{ Equity / loans } & $-0,883$ & & 4,284 & & 0,215 & \\
\hline & & $-10,86$ & 0 & $-6,78$ & 0,01 & $-2,11$ & 0,04 \\
\hline \multirow{2}{*}{ Est03 } & \multirow{2}{*}{ Working capital / total assets } & $-2,913$ & & \multirow{2}{*}{ - } & \multirow{2}{*}{ - } & $-0,707$ & \\
\hline & & $-11,78$ & 0 & & & $-3,01$ & 0 \\
\hline \multirow{2}{*}{ Ren05 } & \multirow{2}{*}{ Profit / total assets } & \multirow[b]{2}{*}{ - } & \multirow{2}{*}{ - } & 34,773 & & \multirow{2}{*}{ 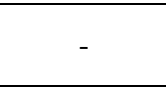 } & \multirow{2}{*}{ - } \\
\hline & & & & $-14,09$ & 0 & & \\
\hline \multirow{2}{*}{ Sol06 } & \multirow{2}{*}{ Equity / total assets } & 4,823 & & $-17,348$ & & $-1,171$ & \\
\hline & & $-12,63$ & 0 & $-12,77$ & 0 & $(-4,19)$ & 0 \\
\hline \multirow{2}{*}{ Liq05 } & \multirow{2}{*}{$\begin{array}{c}\text { Cash flow Resources Generated } \\
\text { / total assets }\end{array}$} & $-3,891$ & & \multirow{2}{*}{ 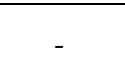 } & \multirow{2}{*}{ - } & $-0,945$ & \\
\hline & & $-13,71$ & 0 & & & $-3,5$ & 0 \\
\hline \multirow{4}{*}{ Liq12 } & \multirow{2}{*}{ No credit period } & 1,466 & & \multirow{2}{*}{ - } & \multirow{2}{*}{ - } & $-0,356$ & \\
\hline & & $-16,51$ & 0 & & & $(-2,91)$ & 0 \\
\hline & \multirow{2}{*}{ Intercept } & $-0,312$ & & 3,102 & & 0,576 & \\
\hline & & - & - & $-17,18$ & 0 & $-9,06$ & 0 \\
\hline & \multirow{2}{*}{ Global sig. } & 52,371 & \multirow{2}{*}{0} & 90,257 & \multirow{2}{*}{0} & 10,863 & \multirow{2}{*}{0} \\
\hline & & $(2)$ & & $(2)$ & & (f) & \\
\hline & Hit rate, failed companies & $70,00 \%$ & & $88,30 \%$ & & $70,00 \%$ & \\
\hline & Hit rate, healthy companies & $90,00 \%$ & & $90,00 \%$ & & $90,00 \%$ & \\
\hline & Hit rate, all companies & $80,00 \%$ & & $89,20 \%$ & & $80,00 \%$ & \\
\hline
\end{tabular}

Table 6: Models "Omega-global" - joint estimation four years prior to failure

\begin{tabular}{|c|c|c|c|c|c|c|c|}
\hline & Variables & \multicolumn{2}{|c|}{ MDA } & \multicolumn{2}{|c|}{ Logit } & \multicolumn{2}{|c|}{ LR } \\
\hline & & Coef.(f) & Sig. & Coef.(t) & Sig. & Coef.(wald) & Sig. \\
\hline \multirow{2}{*}{ Apl04 } & \multirow{2}{*}{ Profit / loans } & 0,399 & & \multirow{2}{*}{ - } & \multirow{2}{*}{ - } & $-0,087$ & \\
\hline & & $-32,41$ & 0 & & & $(-2,00)$ & 0,05 \\
\hline \multirow{2}{*}{ End03 } & \multirow{2}{*}{ Equity / loans } & 0,376 & & \multirow{2}{*}{ - } & \multirow{2}{*}{ - } & $-0,082$ & \\
\hline & & $-50,19$ & 0 & & & $(-3,29)$ & 0 \\
\hline \multirow{2}{*}{ Est03 } & \multirow{2}{*}{ Working capital / total assets } & 1,159 & & $-3,711$ & & $-0,253$ & \\
\hline & & $-67,68$ & 0 & $-44,24$ & 0 & $(-4,29)$ & 0 \\
\hline
\end{tabular}


Bankruptcy Prediction Models in Galician Companies Application of Parametric Methodologies and Artificial Intelligence

\begin{tabular}{|c|c|c|c|c|c|c|c|}
\hline \multirow{2}{*}{ Rot06 } & \multirow{2}{*}{ Sales / total assets } & 0,011 & & \multirow[b]{2}{*}{ - } & \multirow{2}{*}{-} & $-0,002$ & \\
\hline & & $-39,25$ & 0 & & & $(-2,25)$ & 0,03 \\
\hline \multirow{9}{*}{ Liq05 } & \multirow{2}{*}{$\begin{array}{l}\text { Cash flow rec. Gdos. / activo } \\
\text { total }\end{array}$} & 1,975 & & $-11,254$ & & $-0,431$ & \\
\hline & & $-95,74$ & 0 & $-61,76$ & 0 & $(-4,55)$ & 0 \\
\hline & \multirow{2}{*}{ Intercept } & $-0,275$ & & 0,6743 & & 0,56 & \\
\hline & & - & - & $-21,69$ & 0 & $-23,49$ & 0 \\
\hline & \multirow{2}{*}{ Global sig. } & 139,846 & \multirow{2}{*}{0} & 217,915 & \multirow{2}{*}{0} & 32,414 & \multirow{2}{*}{0} \\
\hline & & $(2)$ & & $(2)$ & & (f) & \\
\hline & Hit rate, failed companies & $75,00 \%$ & & $78,30 \%$ & & $75,00 \%$ & \\
\hline & Hit rate, healthy companies & $82,50 \%$ & & $82,50 \%$ & & $82,50 \%$ & \\
\hline & Hit rate, all companies & $78,80 \%$ & & $80,40 \%$ & & $78,80 \%$ & \\
\hline
\end{tabular}

While we were working in this paper, in February 2010, a relevant local company filed for bankruptcy. Recent audit reports available (2004 and 2006) were clean, but our prediction models supplied clear warning signs: both the MDA and the MRL models point to bankruptcy in $100 \%$ of the simulations, while LOGIT warns in $37.5 \%$ of them (Table 7 ).

Table 7: A real, particular, case of application of forecasting models

\begin{tabular}{|l|l|l|l|l|}
\hline Date & $\mathbf{1 5 / 1 1 / 2 0 0 7}$ & $\mathbf{1 5 / 1 1 / 2 0 0 6}$ & $\mathbf{1 5 / 1 1 / 2 0 0 5}$ & $\mathbf{1 5 / 1 1 / 2 0 0 4}$ \\
\hline MDA 1 AA & FAILURE & FAILURE & FAILURE & FAILURE \\
\hline MDA 2 AA & FAILURE & FAILURE & FAILURE & FAILURE \\
\hline MDA 3 AA & FAILURE & FAILURE & FAILURE & FAILURE \\
\hline MDA 4 AA & FAILURE & FAILURE & FAILURE & FAILURE \\
\hline MDA GLOBAL & FAILURE & FAILURE & FAILURE & FAILURE \\
\hline LOGIT 1 AA & FAILURE & FAILURE & FAILURE & FAILURE \\
\hline LOGIT 2 AA & FAILURE & FAILURE & SOLVENT & SOLVENT \\
\hline LOGIT 3 AA & SOLVENT & SOLVENT & SOLVENT & SOLVENT \\
\hline LOGIT 4 AA & SOLVENT & SOLVENT & SOLVENT & SOLVENT \\
\hline LOGIT GLOBAL & SOLVENT & SOLVENT & SOLVENT & SOLVENT \\
\hline MRL 1 AA & FAILURE & FAILURE & FAILURE & FAILURE \\
\hline MRL 2 AA & FAILURE & FAILURE & FAILURE & FAILURE \\
\hline MRL 3 AA & FAILURE & FAILURE & FAILURE & FAILURE \\
\hline MRL 4 AA & FAILURE & FAILURE & FAILURE & FAILURE \\
\hline MRL GLOBAL & FAILURE & FAILURE & FAILURE & FAILURE \\
\hline
\end{tabular}

\subsection{IA Applications: neural networks}

We use a neural network application to identify those companies that have a high probability of failure. When modelling the concepts of failure and financial distress, we used a Perceptron architecture with Multilayer Back-Propagation Learning with two hidden layers of nodes 8 and 6 respectively. Depending on the input variables, in all cases financial ratios, we have been used two types of configurations. On the one hand, we considered as input variables all financial ratios selected for this study with some minor changes to reduce the total number of variables: we have considered only the 28 most significant financial ratios of factor analysis, that is, those with greater weight in the factor and/or an eigenvalue greater than 0.8 on 
factor analysis. Extreme values have not been debugged - this is not a relevant issue for neural models. The final settings are $28 \times 8 \times 6 \times 1$ and $51 \times 8 \times 6 \times 1$.

Figure 1 shows the network architecture we have employed.

\section{Figure 1: Multilevel Perceptron network structure}

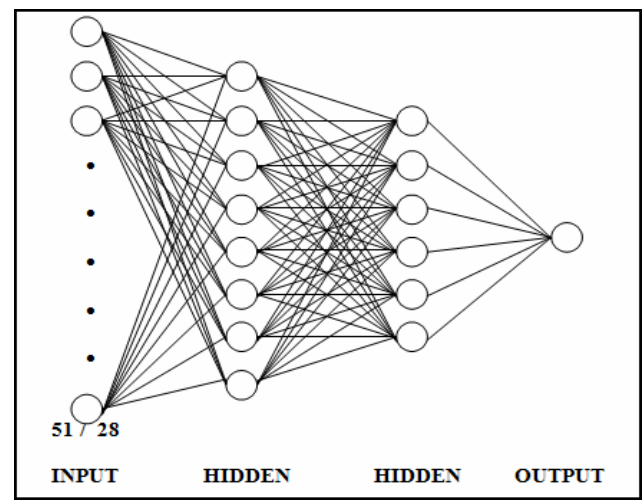

Processing nodes have as a sigmoid transfer function centred at zero on $\mathrm{X}$ and $\mathrm{Y}$ axes, hyperbolic-type function. $\mathrm{Y}$-axis has an output range between -1 and 1 . The environment normalizes the entries into that range, and de-normalizes the outputs.

The network was built with the development environment of Neuro-Solutions [97 Neuro-Solutions Version 3.02, Neuro Dimension Inc. 1997], running on PC platform under Windows 98, with the back propagation algorithm designed by Rumelhat, Hinton and Williams (1986), with default training coefficients: a value less than 1 in all connection weights between layers, and higher in the input layer, but always within the range between 0 and 1 . The time factor has remained constant in all layers (0.7). During the training process we carried between 2,000 and 3,000 iterations or "times" of training, and we get optimal classification levels; we tried to avoid over fitting biases. The network gets very high rate levels, even though the number of iterations is only moderate. On the other side, the predictive ability of models decreases in the validation phase: parametric models outperform neural network except in years 3 and 4.

Table 8: Perceptron multilevel networks: hit rate in training stage

\begin{tabular}{|c|c|c|c|c|c|c|}
\hline & \multicolumn{3}{|c|}{$\begin{array}{c}\text { NETWORK } \\
\mathbf{5 1} \times \mathbf{5 0} 8 \times \mathbf{6} \times \mathbf{1}\end{array}$} & \multicolumn{3}{c|}{$\begin{array}{c}\text { NETWORK } \\
\mathbf{2 8} \mathbf{8} \mathbf{6} \times \mathbf{1}\end{array}$} \\
\hline $\begin{array}{c}\text { SAMPLE } \\
\text { (60 HEALTHY - 60 FAILED) }\end{array}$ & HEALTHY & Failed & TOTAL & HEALTHY & Failed & TOTAL \\
\hline YEAR 1 BEFORE FAILURE & 100,0 & 98,3 & 99,2 & 98,3 & 100,0 & 99,2 \\
\hline YEAR 2 BEFORE FAILURE & 100,0 & 98,3 & 99,2 & 100,0 & 98,3 & 99,2 \\
\hline
\end{tabular}


Bankruptcy Prediction Models in Galician Companies Application of Parametric Methodologies and Artificial Intelligence

\begin{tabular}{|c|c|c|c|c|c|c|}
\hline YEAR 3 BEFORE FAILURE & 98,3 & 100,0 & 99,2 & 98,3 & 100,0 & 99,2 \\
\hline YEAR 4 BEFORE FAILURE & 98,3 & 100,0 & 99,2 & 100,0 & 96,7 & 98,3 \\
\hline GLOBAL MODEL & 93,8 & 93,8 & 93,8 & 95,0 & 91,7 & 93,3 \\
\hline
\end{tabular}

Table 9: Perceptron multilevel networks: hit rate in validation stage

\begin{tabular}{|c|c|c|c|c|c|c|}
\hline & \multicolumn{3}{|c|}{$\begin{array}{c}\text { NETWORK } \\
\mathbf{5 1} \text { ́ 50 8 x 6 x 1 }\end{array}$} & \multicolumn{3}{c|}{$\begin{array}{c}\text { NETWORK } \\
\text { 28 x x 6 x 1 }\end{array}$} \\
\hline VALIDATION SAMPLE & HEALTHY & FAILURE & TOTAL & HEALTHY & FAILURE & TOTAL \\
\hline $\begin{array}{c}\text { YEAR 1 BEFORE } \\
\text { FAILURE } \\
\text { (29 Failed - 284 Healthy) }\end{array}$ & 91,5 & 96,6 & 92,0 & 93,7 & 96,6 & 93,9 \\
\hline $\begin{array}{c}\text { YEAR 1 BEFORE } \\
\text { FAILURE } \\
\text { (29 Failed - 284 Healthy) }\end{array}$ & 79,2 & 82,7 & 79,6 & 82,7 & 82,7 & 82,7 \\
\hline $\begin{array}{c}\text { YEAR 1 BEFORE } \\
\text { FAILURE } \\
\text { (29 Failed - 284 Healthy) }\end{array}$ & 78,5 & 72,4 & 78,0 & 83,8 & 79,3 & 83,4 \\
\hline $\begin{array}{c}\text { YEAR 1 BEFORE } \\
\text { FAILURE } \\
\text { (15 Failed - 284 Healthy) }\end{array}$ & 63,4 & 93,3 & 64,9 & 73,6 & 73,3 & 73,6 \\
\hline $\begin{array}{c}\text { MODELO GLOBAL } \\
\text { (102Failed - 1.136 Healthy) }\end{array}$ & 80,4 & 82,3 & 80,5 & 83,2 & 86,3 & 83,4 \\
\hline
\end{tabular}

\section{Discussion}

The four models offer a very important effectiveness in predicting business failure in, at least, the four years prior to the event. Logit analysis offers a very acceptable hit level of $90 \%$ in the four years prior to failure, and also MDA models are able to anticipate most of distress situations - this is remarkable, given that the fulfilment of normality hypothesis is doubtful.

All final models operate on a core set of eight financial ratios; however its configuration is slightly different depending on prediction horizon. Two and three years prior to the event, optimal prediction levels are achieved with simple models (univariate and bivariate, except in third year, where the MDA model requires more variables). As we approach the failure event the number of distressed variables increases, and a specific profile emerges: difficulties to generate resources, mainly profit, and an increasing leverage. Failed firms show abnormal values for the following ratios: APL04, REN05 and SOL06, which therefore have high explanatory and predictive power. APL04 (Net Income / Total Liabilities) is also a relevant factor, as previous works stated.

A year before the failure event, and also four years before, we need to include up to five variables to get an acceptable predictive capacity. This suggests that the predictive power of the models weakens in long time horizons; maybe because companies do not yet have a defined profile of failure, hence the models require a 
greater volume of evidence to make a right classification. We believe that these companies try to stay on the market by adopting policies that, even though may help defer the event, cause widespread financial imbalances: obtain liquidity through the realization of assets, significant short-term debt, deterioration of the financial structure, reduce prices to maintain the level of sales, reduce customers credit, difficulties to maintain trade credits, earnings from discontinued operations, etc.

Both network models offer a satisfactory performance - analytic power is higher in 28-variable models. Given that we define discriminant variables as the most significant in each factor resulting from principal components analysis, the elimination of "noise" in the network causes a higher percentage of success in the validation stage.

As anticipated, the predictive ability of neural network models is usually higher than that of multivariate parametric models, although the performance of the latter is not far away. The exception to the above, albeit partially, is presented in years 3 and 4 before the failure, in which periods the network model composed of 28 variables, with a percentage of correct answers of $83.4 \%$ and $73.6 \%$, respectively, exceeds the overall rate of successes obtained with discriminant analysis and linear regression, leading to better classify the failed companies. Regarding the overall model, neural networks results are as good as those from parametric multivariate models.

In summary, these findings come to agree with other investigations in the sense that while the neural networks are a tool to keep in mind in forecasting business failure, they do not clearly outperform the most common and recognized multivariate statistical techniques.

\section{The role of audit in predicting financial failure}

The high predictive power achieved with the estimated models is due to the existence of clear differences between healthy and failed companies. This is true, even though our notion of financial distress includes several situations that not necessarily lead to a immediate bankruptcy. However a large proportion of failed firms were able to get clean audit reports, or minor qualifications.

In a now classic work, Altman and McGough (1974) verified that the Z model outperformed the audit in detecting signs of stress or financial risk, at horizons of one and two years before the event and with reference to the significant qualifications affecting the going-concern. His explanation is that audit reports consider these financial tensions as temporary circumstances that the company can solve; thus, auditors do not put in question their survival. But the examples of companies that fail shortly after receiving reports clean (or without obvious signs of alert) are remarkable. 
Later works came to agree with these hypothesis (e.g. Moiz, 1995; Citron and Taffler, 2001) and suggest that auditors may underestimate the financial risk factors, either due to a bias in favour of the continuity of the company - the general tendency to align with your current financial status - or to the fear that the revelation of these difficulties would further exacerbate the imbalances - the self-fulfilling prophecy hypothesis.

In order to verify the ability of the audit to provide warning signs, we selected a sample of audited companies that experienced financial difficulties over the past four years (validation sample.) Again, we use the extended concept of financial failure. First we check if the audit reports contain significant evidences about the risks faced by the companies, and provide accurate warning signals to anticipate failure. We then apply the models described in previous sections, providing additional evidence about the predictive ability of models and their comparative effectiveness in relation to the audit.

\subsection{Selection of validation sample}

The validation sample was selected using the same criteria used for the estimation sample used in the first phase of our study, with one obvious additional requirement: companies must be audited and reports must be available. SABI enrolls 72.581 Galician companies; 46.820 of them were audited but only 1.633 of the reports was available. On the other side, data about defaults and/or returned trade effects were obtained from RAI and BADEXCUG public registries. We found 434 records for those companies (some of them were listed in both registries); again, real estate industry was excluded. The final sample validation includes 38 companies; it is a seemingly small number, but it should be noted that it's a rather special category of companies: audited businesses whose financial difficulties were not revealed by going concern disclosures by auditors. Twenty-one of these companies experienced repeated incidents relevant to RAI and/or BADEXCUG, but did not go to bankrupt at the time of writing this work.

\subsection{Content of audit reports}

Qualifications were obtained from auditors' reports. All of the caveats were minor questions, and none of them expressed real warnings about going concern, financial distress or bankruptcy. Some of the qualifications were as follows:

- The company has valued its fixed assets at their purchase price, net of amortization, excluding impairment losses in value. However, accounting rules state that there will be an impairment loss of intangible assets when the book value exceeds their recoverable amount. At the date of this report, we do not have evidence on the recoverable value of fixed assets related to productive activity, for machinery, equipment, other facilities and other assets, net book value amounts to n.nnn thousand. Therefore, we cannot conclude on the reasonableness of the valuation of these assets and 
International Journal of Economics \& Business Administration, I (1), 2013

130 Pablo de Llano Monelos - Manuel Rodríguez López- Carlos Piñeiro Sánchez

assumes a limitation on the scope of our work have not received the final business plan for the coming years, so we do not have the evidence necessary to analyze the recoverability Tax Credits on and ...

- We did not attend the physical count of inventory at the end on 31 December totalling n.nnn.nnn nnnn 'nn $€$, because we had not been engaged to audit the company yet; thus it has not been possible to verify the stock on that date by performing alternative audit procedures.

- The society is still implementing a new computer-based MIS for production control and cost management, so it was not possible to determine the costs attributable to each of their buildings during the year, which prevented us from reasonably evaluating the valuation of stock at year end; we could not apply other alternative audit procedures to a satisfactory degree.

- The corporation is, as in the previous year, immersed in several litigations, as disclosed in note nn of memory, with one of its partners who owns nn.n percent of the shares. If this situation persists for a long time, it could undermine the future viability of the company.

- Due to different interpretations of tax regulations in force, contingent liabilities may be difficult to assess objectively. However, in the opinion of society, these liabilities should not significantly affect the annual accounts as a whole. If the company had complied with the principle of prudence, a provision should have been recorded with the amount of n.nnn thousands of euros n.nnn listed in section d). Iii. "Debtor" of balance sheet. In this case, the loss for the year would increase to n.nnn 'nn thousands of euros, and Article 260 of TRLSA should be applicable.

\subsection{Audit VS Parametric Models of Forecast}

Table 8 shows the results of the simulation carried out on the validation sample; we shoe the hit rates achieved in the classification of the companies given the fact they have or not experienced financial stress or a definitive bankruptcy.

Table 8: Hit rates of “Omega Models” on the validation sample

\begin{tabular}{|l|l|l|}
\hline \multicolumn{3}{|l|}{ Pronóstico global } \\
\hline MDA 1 AA & LOGIT 1 AA & MRL 1 AA \\
$91,5 \%$ & $74,2 \%$ & $97,0 \%$ \\
\hline MDA 2 AA & LOGIT 2 AA & MRL 2 AA \\
$89,4 \%$ & $55,9 \%$ & $94,5 \%$ \\
\hline MDA 3 AA & LOGIT 3 AA & MRL 3 AA \\
$99,6 \%$ & $54,7 \%$ & $94,9 \%$ \\
\hline MDA 4 AA & LOGIT 4 AA & MRL 4 AA \\
$89,4 \%$ & $55,9 \%$ & $86,0 \%$ \\
\hline MDA GLOBAL & LOGIT GLOBAL & MRL GLOBAL \\
$94,5 \%$ & $53,4 \%$ & $98,3 \%$ \\
\hline
\end{tabular}


Bankruptcy Prediction Models in Galician Companies Application of Parametric Methodologies and Artificial Intelligence

\begin{tabular}{|c|c|c|}
\hline \multicolumn{3}{|c|}{ Año 1.a.a } \\
\hline MDA 1 AA & LOGIT 1 AA & MRL 1 AA \\
$94,9 \%$ & $74,6 \%$ & $91,5 \%$ \\
\hline MDA 2 AA & LOGIT 2 AA & MRL 2 AA \\
$91,5 \%$ & $67,8 \%$ & $88,1 \%$ \\
\hline MDA 3 AA & LOGIT 3 AA & MRL 3 AA \\
$100,0 \%$ & $69,5 \%$ & $89,8 \%$ \\
\hline MDA 4 AA & LOGIT 4 AA & MRL 4 AA \\
$89,8 \%$ & $69,5 \%$ & $69,5 \%$ \\
\hline MDA GLOBAL & LOGIT GLOBAL & MRL GLOBAL \\
$98,3 \%$ & $72,9 \%$ & $93,2 \%$ \\
\hline \multicolumn{3}{|c|}{ Año 3.a.a } \\
\hline MDA 1 AA & LOGIT 1 AA & MRL 1 AA \\
$91,50 \%$ & $76,30 \%$ & $100,00 \%$ \\
\hline MDA 2 AA & LOGIT 2 AA & MRL 2 AA \\
$89,80 \%$ & $52,50 \%$ & $98,30 \%$ \\
\hline MDA 3 AA & LOGIT 3 AA & MRL 3 AA \\
$100,00 \%$ & $47,50 \%$ & $98,30 \%$ \\
\hline MDA 4 AA & LOGIT 4 AA & MRL 4 AA \\
$86,40 \%$ & $49,20 \%$ & $91,50 \%$ \\
\hline MDA GLOBAL & LOGIT GLOBAL & MRL GLOBAL \\
$93,20 \%$ & $42,40 \%$ & $100,00 \%$ \\
\hline
\end{tabular}

\begin{tabular}{|c|c|c|}
\hline \multicolumn{3}{|c|}{ Año 2.a.a } \\
\hline MDA 1 AA & LOGIT 1 AA & MRL 1 AA \\
$89,80 \%$ & $72,90 \%$ & $98,30 \%$ \\
\hline MDA 2 AA & LOGIT 2 AA & MRL 2 AA \\
$86,40 \%$ & $57,60 \%$ & $96,60 \%$ \\
\hline MDA 3 AA & LOGIT 3 AA & MRL 3 AA \\
$100,00 \%$ & $54,20 \%$ & $94,90 \%$ \\
\hline MDA 4 AA & LOGIT 4 AA & MRL 4 AA \\
$89,80 \%$ & $54,20 \%$ & $93,20 \%$ \\
\hline MDA GLOBAL & LOGIT GLOBAL & MRL GLOBAL \\
$91,50 \%$ & $52,50 \%$ \\
\hline \multicolumn{3}{|c|}{ Año 4.a.a } \\
\hline MDA 1 AA & LOGIT 1 AA & MRL 1 AA \\
$89,80 \%$ & $72,90 \%$ & $98,30 \%$ \\
\hline MDA 2 AA & LOGIT 2 AA & MRL 2 AA \\
$89,80 \%$ & $45,80 \%$ & $94,90 \%$ \\
\hline MDA 3 AA & LOGIT 3 AA & MRL 3 AA \\
$98,30 \%$ & $47,50 \%$ & $96,60 \%$ \\
\hline MDA 4 AA & LOGIT 4 AA & MRL 4 AA \\
$91,50 \%$ & $50,80 \%$ & $89,80 \%$ \\
\hline MDA GLOBAL & LOGIT GLOBAL & MRL GLOBAL \\
$94,90 \%$ & $45,80 \%$ & $100,00 \%$ \\
\hline
\end{tabular}

\section{Summary and conclusions}

We have developed a set of models able to predict the financial failure of firms located in the Autonomous Community of Galicia, to cover the lack of studies of this type for this geographical area. These models are based on financial ratios, and have been estimated by well-known multivariable methods; the results support the value of financial ratios and financial statements as sources of useful evidences to evaluate financial distress and the risk of financial failure. Of the 59 financial ratios tested, the highest information content is concentrated in profitability, liquidity, leverage and solvency. Our results support the linkage between Profitability and Cash Flow. Distressed firms are less able to generate financial resources; this leads to an increased leverage, to an increasing pressure over income, to the erosion of the equity, and finally to bankruptcy; failed firms usually show an abnormal negative working capital, diminishing client credit periods, lowering prices, and an imbalanced liquidity.

Models show differences between failed and not failed companies become more evident about one year before the event. We believe this is because distressed companies try to avoid bankruptcy by adopting extreme financial decisions, as above mentioned. These arrangements can defer, but usually not avoid, bankruptcy: imbalances make more and more evident during the last year, and affect directly cash flow generation, asset turnover and leverage. Our short-term models are able to make accurate predictions by examining solvency, liquidity and profitability. The "OMEGA" model family offers consistent and very accurate predictions over failed companies; the percentage of errors is slightly higher for healthy companies in the long run. Ob the other side, the average rate of success of short-term models is very 
high in both groups. Given that the decision maker does not really know when the failure event will happen (if so), we believe that the joint application of the five models can provide very useful information, revealing which companies are prone to suffer financial distress in the future.

The prototype of neural network offers optimal levels of classification with a small number of iterations. In the validation phase, the ability of the network lowers, but is still appealing even though some ratios are eliminated. This confirms that the elimination of "noise" in the network improves its predictive ability. The forecasts are consistent and similar to those obtained with multivariate parametric models. From a global perspective, the neural network models is unable to outperform parametric models, even though provides quite acceptable results, especially in the real implementation with failed companies.

Both groups of models provide a useful decision support tool for a wide range of users who need to assess the financial risk of a company: managers, external auditors, analysts, creditors, financial institutions, investors, public agencies, etc. We believe they clearly outperform external audit in revealing warning signs about financial distress.

Our study also points out the main determinants of business failure among Galician companies, and the stages they pass through when approaching bankruptcy.

- Increase cash flow generation and profitability.

- Increase the ability to dynamically adapt financial policy to environment changes.

- Increase equity and self-financing, and fit financial structure to financial risk.

It is important to note that these models are not an alternative to the audit: they depend on the reliability of financial information, which is guaranteed by the external audit: auditor's responsibilities focus on regulatory compliance, rather than monitoring management quality. In fact going-concerns are quite abstract and in some extent subjective, and it might be extremely dangerous to issue a wrong or illtimed warning. But a going concern disclosure should also reveal the actions that the company intends to implement to correct the situation, thus reducing uncertainty and increasing financial statements reliability.

\section{References}

Altman, E.I. (1968), "Financial Ratios, Discriminant Analysis and the Prediction of Corporate Bankruptcy”, The Journal of Finance, XXIII (4), pp. 589-609.

Altman, E.I. (2000), "Predicting Financial Distress of Companies: Revisiting the Z-Score and ZETA@ Models”, Working Paper, NYU Salomon Center, Julio. 
Altman, E.I., Haldeman, R.C and Narayanan, P. (1977), “ZETA Análisis: A New Model to Identify Bankruptcy Risk Corporations”, Journal of Banking and Finance, , pp. 29-54.

Altman, E.I. and McGough, Y.T. (1974), "Evaluation of a Company as a Going Concern”, Journal of Accountancy, pp. 50-57.

Arnedo, L., Lizarraga, F. and Sanchez, S. (2008), "Going-concern Uncertainties in Prebankrupt Audit Reports: New Evidence Regarding Discretionary Accruals and Wording Ambiguity”, International Journal of Auditing, 12(1), pp. 25-44.

Beaver, W. (1966), "Financial Ratios as Predictors of Failure", Journal of Accounting Research, 5 (Empirical Research in Accounting: Selected Studies), pp. 71-111.

Bell, T.B., Ribar, G.S. and Verchio, J. (1990), "Neural Nets versus Logistic Regression: A Comparison of Each Model's Ability to Predict Commercial Bank Failures", in Srivastava, R.P. (Ed.) Auditing Symposium X, Deloitte \& Touche, Symposium on Auditing Problems; Kansas, pp. 29-53.

Brockett, P., Golden, L., Jang, J. and Yang, C. (2006), “A Comparison of Neural Network, Statistical Methods, and Variable Choice for Life Insurers' Financial Distress Prediction”, The Journal of Risk and Insurance, 73(3), pp. 397-419.

Carcello J. and Palmrose, Z. (1994), Auditor Litigation and Modified Reporting on Bankrupt Clients, Journal of Accounting Research, Suppl. pp. 1-30.

Citron, D. and Taffler, R. (2001), "Ethical Behaviour in the U.K. Audit Profession: The Case of the Self-Fulfilling Prophecy Under Going-Concern Uncertainties”, Journal of Business Ethics, pp. 353-363.

Dubois, D. and Prade, H. (1992), "Putting Rough Sets and Fuzzy Sets Together, in Intelligent Decision Support”, in Slowinski, R. (Ed.) Handbook of Applications and Advances in Rough Set Theory, Kluwer Academic, Dordrecht, pp. 203-232.

Elam, R. (1975), "The Effect of Lease Data on the Predictive Ability of Financial Ratios", The Accounting Review, pp. 25-43.

Ferrando, M. and Blanco, F. (1998), "La Previsión del Fracaso Empresarial en la Comunidad Valenciana: Aplicación de los Modelos Discriminante y Logia”, Revista Española de Financiación y Contabilidad, XXVII 95, pp. 499-540.

Frydman, H., Altman, E.I. and Kao, D.L. (1985), "Introducing Recursive Partitioning for Financial Classification: The Case of Financial Distress”, The Journal of Finance, XL 1, pp. 269-291.

Gabás Tribo, F. (1990), Técnicas Actuales de Análisis Contable. Evaluación de la Solvencia Empresarial, I.C.A.C., Madrid.

Gallego, A.M., Gómez, J.C. and Yánez, L. (1996), "Modelos de Predicción de Quiebras en Empresas No Financieras”, IV Foro de Finanzas, AEFIN, Madrid, pp. 785-804.

Gandía, J.L., García, J.L. and Molina, R. (1995), Estudio Empírico de la Solvencia Empresarial en la Comunidad Valenciana, Instituto Valenciano de Investigaciones Económicas; Valencia.

García, D., Arqués, A. and Calvo-Flores, A. (1995), "Un Modelo Discriminante para Evaluar el Riesgo Bancario en los Créditos a Empresas”, Revista Española de Financiación y Contabilidad, XXIV 82, pp. 175-200.

Gombola, M.J. and Ketz, E. (1983), “A Note on Cash Flow and Classification Patterns of Financial Ratios”, The Accounting Review, LVIII 1, 105-114.

Hansen, J. and W. Messier 1991, "Artificial Neural Networks: Foundations and Application to a Decision Problem:, Expert Systems with Applications, 3, pp. 135-141. 
Keasey, K. and Watson, R. (1987), "Non-Financial Symptoms and the Prediction of Small Company Failure. A Test of Argenti's Hypotheses", Journal of Business Finance and Accounting, 14(3), pp. 335-354.

Koh, H. and Tan, S. (1999), "A Neural Network Approach to the Prediction of Going Concern Status”, Accounting and Business Research, 29(3), pp. 211-216.

Laffarga, J., Martín, J.L. and Vázquez, M.J. (1985), "El Análisis de la Solvencia en las Instituciones Bancarias: Propuesta de una Metodología y Aplicaciones a la Banca Española”, Esic Market, Abril-Junio, pp. 51-73.

Lam, K. and Mensah, Y. (2006), “Auditors' Decision-making Under Going-concern Uncertainties in Low Litigation-risk Environments: Evidence from Hong Kong”, Journal of Accounting and Public Policy, 25, pp. 706-739.

Lizarraga, F. (1997), "Utilidad de la Información Contable en el Proceso de Fracaso: Análisis del Sector Industrial de la Mediana Empresa Española”, Revista Española de Financiación y Contabilidad, XXVI 92, pp. 871-915.

López, D., Moreno, J. and Rodríguez, P. (1994), "Modelos de Previsión del Fracaso Empresarial: Aplicación a Entidades de Seguros en España”, Esic Market, 84,pp.83-125.

Martin, D. (1977), “Early Warning of Bank Failure”, Journal of Banking and Finance, 1(3), pp. 249-276.

McKee, T. (2003), "Rough Sets Bankruptcy Prediction Models versus Auditor Signalling Rates”, Journal of Forecasting, 22, pp. 569 - 586.

McKee, T. and Lensberg, T. (2002), "Genetic Programming and Rough Sets: a Hybrid approach to Bankruptcy Classification”, European Journal of Operational Research, 138, pp. 436-451.

Messier, W. and Hansen, J. (1988), "Inducing Rules for Expert System Development: an example using Default and Bankruptcy Data”, Management Science 34(12),.1403-1415.

Moizer, P. (1995), "An Ethical Approach to the Choices Faced by Auditors", Critical Perspectives on Accounting, October, pp. 415-431.

Mora, A. (1994a), "Los Modelos de Predicción del Fracaso Empresarial: Una Aplicación Empírica del Logia”, Revista Española de Financiación y Contabilidad, 78, 203-233.

Mora, A. (1994b), "Limitaciones Metodológicas de los Trabajos Empíricos sobre la Predicción del Fracaso Empresarial”, Revista Española de Financiación y Contabilidad, 80, pp. 709-732.

Moyer, R.C. (1977), "Forecasting Financial Failure: A Re-examination”, Financial Management, 6(1), pp. 11-17.

Norton, C.L. and Smith, R.E. (1979), “A Comparison of General Price Level and Historical Cost Financial Statements in the Prediction of Bankruptcy", The Accounting Review, Enero, pp. 72-87.

O' Clock, P. and Devine, K. (1995), “An Investigation of Framing and Firm Size on the Auditor's Going Concern Decision”, Accounting \& Business Research, 25(99), 197-207.

Ohlson, J.A. (1980), "Financial Ratios and the Probabilistic Prediction Bankruptcy”, Journal of Accounting Research, 18(1), pp. 109-131.

Peel, M.J., Peel, D.A. and Pope, P.F. (1986), "Predicting Corporate Failure. Some Results for the UK Corporate Sector, Omega”, The International Journal of Management Science, 14(1), pp. 5-12.

Pina, V. (1989), "La Información Contable en la Predicción de la Crisis Bancaria 19771985”, Revista Española de Financiación y Contabilidad, 18(58), pp. 309-338. 
Pina, V. (1992), "Estructura y Clasificación de los Ratios: Principio de Devengo vs. Flujos de Caja”, Revista Española de Financiación y Contabilidad, 21(70), pp. 9-27.

Pindado, J., Rodrigues, L. and De la Torre, C. (2008), "Estimating Financial Distress Likelihood”, Journal of Business Research, 61, pp. 995-1003.

Platt, H.D., Platt, M.B. and Pedersen, J.G. (1994), "Bankruptcy Discrimination With Real Variables”, Journal of Business, Finance and Accounting, 21(4), pp. 491-510.

Ramírez, I. (1996), "La Utilidad del Análisis Multivariante para Evaluar la Solvencia de las Pequeñas Empresas”, X Congreso Nacional de AEDEM, Granada, pp. 463-473.

Robinson, D. (2008), “Auditor Independence and Auditor-Provided Tax Service: Evidence from Going-Concern Audit Opinions Prior to Bankruptcy Filings”, Auditing: a Journal of Practice \& Theory, 27(2), pp. 31-54.

Rodríguez, M.C. (1990), La Predicción de las Crisis Empresariales. Modelos para el Sector de Seguros, Universidad de Valladolid, Valladolid.

Rodríguez, J.M. (1989), “Análisis de las Insolvencia Bancarias en España: Un Modelo Empírico”, Moneda y Crédito, 189, pp. 187-227.

Rodríguez, M. (2002), Modelos de Insolvencia en Empresas Gallegas. Aplicación de Técnicas Paramétricas y de Inteligencia Artificial, en Doldán, F. and M. Rodríguez (eds.) La gestión del riesgo de crédito, AECA, Madrid, pp. 73-114.

Rose, P.S., Andrews, W.T. and Giroux, G.A. (1982), Predicting Business Failure: A Macroeconomic Perspective, Journal of Accounting Auditing and Finance, pp. 20-31.

Ruiz, E. and Gómez, N. (2007), “Análisis Empírico de los Factores que Explican la Mejora de la Opinión de Auditoría: Compra de Opinión y Mejora en las Prácticas Contables de la Empresa”, Revista Española de Financiación y Contabilidad, XXXVI 134, 317-350.

Schwartz, K. and Soo, B. (1995), "An Analysis of Form 8-K Disclosures of Auditor Changes by Firms Approaching Bankruptcy”, Auditing: A journal of Practice \& Theory, 14(1), pp. 125-136.

Serrano, C. and Martín, B. (1993), "Predicción de la Quiebra Bancaria Mediante el Empleo de Redes Neuronales Artificiales”, Revista Española de Financiación y Contabilidad, 22(74), pp. 153-176.

Simunic, D. (1984), “Auditing, Consulting and Auditor Independence”, Journal of Accounting Research, 22, pp. 679-702.

Slowinski R. and Zopounidis, C. (1995), "Application of the Rough Set Approach to Evaluation of Bankruptcy Risk", International Journal of Intelligent Systems in Accounting, Finance \& Management, 4(1), pp. 27-41.

Somoza, A. (2001), "La Consideración de Factores Cualitativos, Macroeconómicos and Sectoriales en los Modelos de Predicción de la Insolvencia Empresarial. Su Aplicación al Sector Textil and Confección de Barcelona (1994-1997)”, Papeles de Economía Española, (89-90), pp. 402-426.

Sun, J. and Li, H. (2009), "Financial Distress Early Warning Based on Group Decision Making”, Computers \& Operations Research, 36, pp. 885-906.

Thalassinos, I.E., Liapis, K. and Thalassinos, E.J. (2013), "The Role of the Rating Companies in the Recent Financial Crisis in the Balkan and Black Sea Area", in Karasavvoglou, A. and Polychronidou, P. (Eds.), Economic Crisis in Europe and the Balkans, Contributions to Economics, Springer International Publishing, Switzerland, DOI IO.1007/978-3-319-00494-5_6.

Venuti, E. (2004), “The Going-concern Assumption Revisited: Assessing a Company's Future Viability”, The CPA Journal, Mayo, pp. 40-44. 
Wilkins, M. (1997), “Technical default, Auditors’ Decisions, and Future Financial Distress”, Accounting Horizons, 11(4), pp. 40-48.

Zmijewski, M.E. (1984), "Methodological Issues Related to the Estimation of Financial

Distress Prediction Models”, Journal of Accounting Research, Supplement, pp. 59-82.

\section{Annex: Sample of failed companies (validation sample)}

\begin{tabular}{|c|}
\hline Acerias As Pontes SL \\
\hline Aceriusa SL \\
\hline Astilleros M.Cíes S.L. \\
\hline Aynar Pro XXI SL \\
\hline Ayora Puertos y Obras SL \\
\hline Boupamar \\
\hline Calizas Marinas SA \\
\hline Carpintería Naval José Pérez SL \\
\hline Central Lechera Gallega SA \\
\hline Congelados País SL \\
\hline Congelados Troulo SA \\
\hline Conservas Selectas Mar de Couso SA \\
\hline Coprosider SL \\
\hline Dehesa de Rubiales SL \\
\hline Delio SL \\
\hline Discovi SL \\
\hline Disemba SL \\
\hline Distribuidora Internacional de Alimentación SA \\
\hline Edibar SL \\
\hline Elaboradora de Cefalópodos SA \\
\hline Eurogalia SL \\
\hline Exportadora Shayne SL \\
\hline Fergofrío SL \\
\hline Ferlosa SL \\
\hline Ferralla Lois SL \\
\hline Ferrogres SL \\
\hline Fomento de Áridos y Obras \\
\hline Forum Filatélico SA \\
\hline Galicia Frozen Fish SL \\
\hline Generos de punto Ivan SL \\
\hline
\end{tabular}

\begin{tabular}{|c|}
\hline Generos de Punto Montoto SL \\
\hline Granimondi SA \\
\hline Granitesa \\
\hline Granitos Montefaro SA \\
\hline Gruas y Transportes Vidal \\
\hline Hidrospack SL \\
\hline Hierros Touriño SA \\
\hline Iberoitaliana de Pizarras \\
\hline Industrias Pizarreras Garcia Aguado SL \\
\hline $\begin{array}{l}\text { Lalandi SL } \\
\end{array}$ \\
\hline Lamanor SL \\
\hline Mariscos Coruña SL \\
\hline Mebl y Trans SL \\
\hline MGI Coutier España SL \\
\hline Montajes Industriales del NO SA \\
\hline Montajes Industriales del NO SA \\
\hline Muebles Carballo SA \\
\hline ONTE SA \\
\hline Pescados Muiños SL \\
\hline Plasticos Regueira SL \\
\hline RC Celta de Vigo SAD \\
\hline RC Deportivo de La Coruña \\
\hline Roberto Mourino SA \\
\hline Strategias de Medios Galicia SA \\
\hline Transportes Ramos Piñeiro \\
\hline UNICEN \\
\hline Viajes Vincit SL \\
\hline Vidriera del Atlántico SA \\
\hline Volvoreta \\
\hline
\end{tabular}

